\title{
PATTERN OF SKIN DISEASES IN GERIATRIC PATIENTS ATTENDING TERTIARY CARE CENTRE
}

\author{
P. Gunalan'1, R. Indradevi², P. Oudeacoumar 3 , J. Govardhan 4 , K. Damayandhi', N. Azeem Jaffer ${ }^{6}$, Varsha Medasani', Chitralekhya Rao ${ }^{8}$
}

${ }_{13}^{\text {rd }}$ Year Postgraduate Student, Department of Dermatology, Aarupadai Veedu Medical College and Hospitals (AVMCH), Puducherry. ${ }^{2}$ Associate Professor, Department of Dermatology, Aarupadai Veedu Medical College and Hospitals (AVMCH), Puducherry. ${ }^{3}$ Professor and Head, Department of Dermatology, Aarupadai Veedu Medical College and Hospitals (AVMCH), Puducherry. ${ }^{4}$ Assistant Professor, Department of Dermatology, Aarupadai Veedu Medical College and Hospitals (AVMCH), Puducherry. ${ }_{5}^{5}$ Assistant Professor, Department of Dermatology, Aarupadai Veedu Medical College and Hospitals (AVMCH), Puducherry. ${ }_{6}^{6}{ }^{r d}$ Year Postgraduate Student, Department of Dermatology, Aarupadai Veedu Medical College and Hospitals (AVMCH), Puducherry. $72^{\text {nd }}$ Year Postgraduate Student, Department of Dermatology, Aarupadai Veedu Medical College and Hospitals (AVMCH), Puducherry. $82^{\text {nd }}$ Year Postgraduate Student, Department of Dermatology, Aarupadai Veedu Medical College and Hospitals (AVMCH), Puducherry.

\section{ABSTRACT}

\section{BACKGROUND}

Ageing is a complex process that is due to accumulation of molecular damage over time. Ageing is a biological reality which has its own dynamics beyond human control. People aged 60+ years are generally referred to as older population. Both intrinsic ageing (genetic, chronological ageing) and extrinsic ageing (environmental, photo-ageing) contribute to cutaneous ageing. Common skin disorders in elderly are xerosis, pruritus, dermatoheliosis, seborrheic keratosis, cherry angioma, herpes zoster, dermatophytosis, cellulitis and eczemas. With this background, I propose this study to determine the pattern of cutaneous manifestations in geriatric population attending tertiary care centre.

The aim is to study the pattern of skin diseases in geriatric age.

\section{MATERIALS AND METHODS}

Three hundred patients above 60 years of age attending Dermatology OPD in tertiary care hospital, Puducherry were chosen as study group. The study was carried out for 2 years. A detailed history was taken and general, systemic and cutaneous examination was carried out. All cutaneous and mucosal lesions were recorded. Relevant investigations, which included haemogram, biochemical tests and skin biopsy were performed.

\section{RESULTS}

Total of 300 patients studied of which 197 (66\%) were male and 103 (34\%) were female. Pruritus (44\%) was the commonest complaint noted in this study. Xerosis (93\%) was the commonest physiological change seen. Systemic hypertension (23\%) was the commonest associated systemic illness. Lichen simplex chronicus (11\%) was the commonest eczema. Fungal infection (11\%) was the commonest infection. Bullous pemphigoid (1\%) was the only bullous disorder encountered in this study. Greying of hair (90\%) was the commonest hair change and vertical ridging of nails (40\%) was the commonest physiological nail change seen in this study.

\section{CONCLUSION}

As there is significant number of geriatric population, the increased emphasis on geriatric medicine is inevitable. This present study helps in providing greater understanding of pattern of geriatric dermatoses that aids in early diagnosis and management.

\section{KEYWORDS}

Geriatric Disorders, Xerosis, Pruritus, Eczema.

HOW TO CITE THIS ARTICLE: Gunalan P, Indradevi R, Oudeacoumar P, et al. Pattern of skin diseases in geriatric patients attending tertiary care centre. J. Evolution Med. Dent. Sci. 2017;6(20):1566-1570, DOI: 10.14260/Jemds/2017/344

\section{BACKGROUND}
Ageing is a complex process that is due to accumulation of molecular damage over time. ${ }^{1}$ Ageing is a biological reality which has its own dynamics beyond human control. People aged $60+$ are referred as older population. ${ }^{2}$ Both intrinsic ageing (genetic, chronological ageing) and extrinsic ageing (Environmental, photo-ageing) contribute to cutaneous
Financial or Other, Competing Interest: None.
Submission 02-02-2017, Peer Review 25-02-2017,
Acceptance 03-03-2017, Published 09-03-2017.
Corresponding Author:
Dr. P. Gunalan,
$3^{\text {rd }}$ Year Postgraduate Student,
Department of Dermatology,
Aarupadai Veedu Medical College and Hospitals (AVMCH).
E-mail: drgunalan86@gmail.com
DOI: $10.14260 /$ jemds $/ 2017 / 344$ ageing. ${ }^{3}$ The common skin disorders in elderly are xerosis, pruritus, dermatoheliosis (photo-ageing), benign tumours like seborrheic keratosis, cherry angioma, infections like herpes zoster, dermatophytosis, cellulitis, etc. Eczemas like asteatotic eczema, stasis eczema, discoid eczema and other forms of eczema are common in elderly. ${ }^{3}$ These dermatoses are complicated by chronic systemic diseases in elderly. India is the second largest populated country in the world, with 72 million elderly persons above 60 years of age as of 2001 and the number is likely to increase to 179 million in 2031, and further to 301 million in 2051.4 The population is getting older, with a greater percentage of population over 60 years. Hence an increased emphasis on geriatric medicine is inevitable, geriatric dermatology is a specialty which requires special attention. The present study is to determine the pattern of skin dermatoses in geriatric patients attending tertiary care hospitals. 


\section{MATERIALS AND METHODS}

The present study was carried out from September 2014 to October 2016 in Aarupadai Veedu Medical College and Hospitals, Puducherry. A total of 300 consecutive patients aged over 60 years attending Dermatology OPD were chosen as the study group after written informed consent.

A detailed history was taken regarding the onset and duration of cutaneous manifestations and its association with other systemic illness. Thorough dermatological examination was carried out on all study patients. Relevant investigations which included haemogram, biochemical tests and a skin biopsy were performed, wherever needed.

\section{Inclusion Criteria}

All consenting patients aged above 60 years irrespective of sex were included in the study.

\section{Exclusion Criteria}

Non-consenting patients.

Patients with congenital dermatoses.

\section{RESULTS}

The following observations obtained in the study and the results were tabulated and analysed.

Total of 300 patients above 60 years studied, 197 (66\%) were male and 103 (34\%) were female. Thus, the male: female ratio was $2: 1$.

\begin{tabular}{|c|c|c|}
\hline Sex & No. of Cases & Percentage \% \\
\hline Male & 197 & 66 \\
\hline Female & 103 & 34 \\
\hline \multicolumn{2}{|c|}{ Table 1. Sex Incidence } \\
\hline
\end{tabular}

Table 1 shows majority of the geriatrics were male.

\begin{tabular}{|c|c|c|c|}
\hline $\begin{array}{c}\text { Sl. } \\
\text { No. }\end{array}$ & Condition & $\begin{array}{c}\text { No. of } \\
\text { Cases }\end{array}$ & $\begin{array}{c}\text { Percentage } \\
\text { \% }\end{array}$ \\
\hline 1 & Hypertension & 70 & 23 \\
\hline 2 & Diabetes mellitus & 50 & 16 \\
\hline 3 & Bronchial asthma & 14 & 4.5 \\
\hline 4 & Ischaemic heart disease & 6 & 2 \\
\hline 5 & Cataract & 8 & 2.5 \\
\hline 6 & $\begin{array}{c}\text { Benign prostatic } \\
\text { hypertrophy }\end{array}$ & 4 & 1.5 \\
\hline 7 & Tuberculosis & 6 & 2 \\
\hline 8 & Renal disease & 4 & 1.5 \\
\hline \multicolumn{3}{|c|}{ Table 2. Associated Systemic Conditions } \\
\hline
\end{tabular}

Table 2 shows $54 \%$ of patients had associated systemic illness.

The most common systemic associations of geriatric population were hypertension and diabetic mellitus.

\begin{tabular}{|c|c|c|c|}
\hline $\begin{array}{c}\text { Sl. } \\
\text { No. }\end{array}$ & Conditions & $\begin{array}{c}\text { No. of } \\
\text { Cases }\end{array}$ & $\begin{array}{c}\text { Percentage } \\
\text { \% }\end{array}$ \\
\hline 1 & Xerosis & 279 & 93 \\
\hline 2 & Wrinkling & 264 & 88 \\
\hline 3 & Atrophy & 189 & 63 \\
\hline 4 & $\begin{array}{c}\text { Idiopathic guttate } \\
\text { hypomelanosis }\end{array}$ & 99 & 33 \\
\hline 5 & Senile comedones & 84 & 28 \\
\hline \multicolumn{3}{|c|}{ Table 3. Physiological Changes } \\
\hline
\end{tabular}

All the patients had physiological changes and the commonest change noted was Xerosis.

\begin{tabular}{|c|c|c|c|}
\hline $\begin{array}{c}\text { Sl. } \\
\text { No }\end{array}$ & Conditions & $\begin{array}{c}\text { No. of } \\
\text { Cases }\end{array}$ & $\begin{array}{c}\text { Percentage } \\
\%\end{array}$ \\
\hline 1 & Eczemas & 131 & 43.6 \\
\hline 2 & $\begin{array}{c}\text { Infections and } \\
\text { Infestations }\end{array}$ & 96 & 32 \\
\hline 3 & $\begin{array}{c}\text { Papulosquamous } \\
\text { disorders }\end{array}$ & 42 & 14 \\
\hline 4 & Pigmentary disorders & 42 & 14 \\
\hline 5 & Benign tumours of skin & 202 & 67 \\
\hline 6 & $\begin{array}{c}\text { Miscellaneous } \\
\text { dermatoses }\end{array}$ & 60 & 20 \\
\hline \multicolumn{3}{|c|}{ Table 4. Pattern of skin diseases in geriatric patients } \\
\hline
\end{tabular}

\section{Table 4 Shows}

Eczema was noted in 131 patients (44\%). Among the various types of eczemas, Lichen simplex chronicus was the commonest noted in 33 patients (11\%). 18 patients (6\%) had stasis eczema and seborrhoeic dermatitis. Irritant contact dermatitis and allergic contact dermatitis were seen in 12 patients (4\%). Chronic eczema was seen in 15 patients $(5 \%)$ and subacute eczema was seen in 15 patients (5\%). Hand eczema was seen in 6 patients $(2 \%)$ and 2 patients $(0.5 \%)$ had atopic dermatitis.

Infections and infestations were seen in 96 patients (32\%). Of the various infections, fungal infection was the commonest one followed by viral infections.

Papulosquamous disorders were seen in 42 patients (14\%). 27 patients (9\%) had psoriasis and 15 patients $(5 \%)$ had Lichen planus.

Pigmentary disorders were seen in 42 patients (14\%). Among the various pigmentary disorders, Vitiligo was seen in 27 patients (9\%), Melasma in 15 patients (5\%).

Various benign tumours noted in this study are seborrheic keratosis, acrochordons, melanocytic naevi, and dermoid cyst. No malignant or pre-malignant tumours were noted in this study.

Among the miscellaneous dermatoses, Keratinisation disorders were seen in 15 patients $(5 \%)$, Corns were seen in 12 patients (4\%), Trophic ulcers were seen in 15 patients (5\%), Keloid in 6 patients (2\%) and Keratolysis exfoliativa in 9 patients (3\%). Bullous pemphigoid in 3 patients (1\%) was the only bullous disorder encountered in this study.

Various hair changes noted in this study were greying of hair, Hypertrichosis of pinna, Androgenetic alopecia, and Hirsutism. Greying of hair was the commonest hair change seen in 270 patients (90\%). Hypertrichosis of pinna was seen in 102 patients (34\%) and Androgenic alopecia seen in 60 cases (20\%). Hirsutism was seen in 24 patients (8\%).

The nail changes exceed the number of cases since some cases showed more than one nail change due to ageing. Longitudinal ridging was the commonest nail change noted in this study.

Oral mucosal hyperpigmentation was seen in 74 patients (24.5\%). 


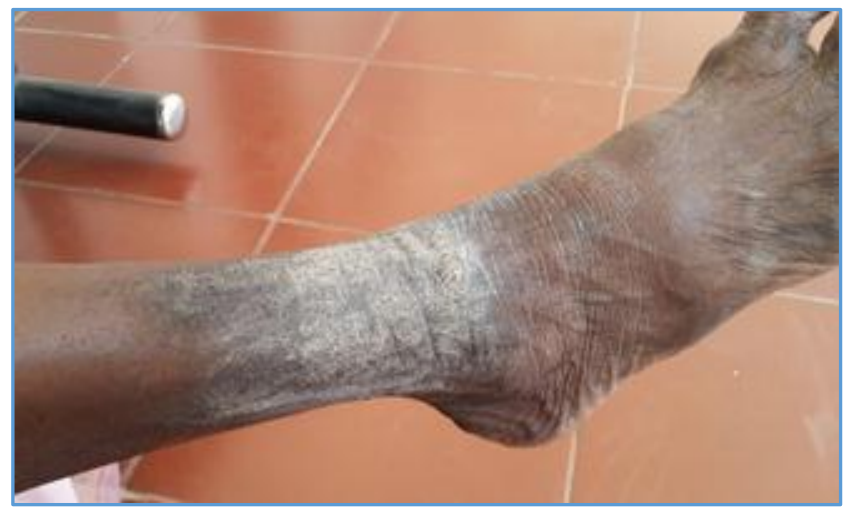

Figure 1. Lichen simplex chronicus leg

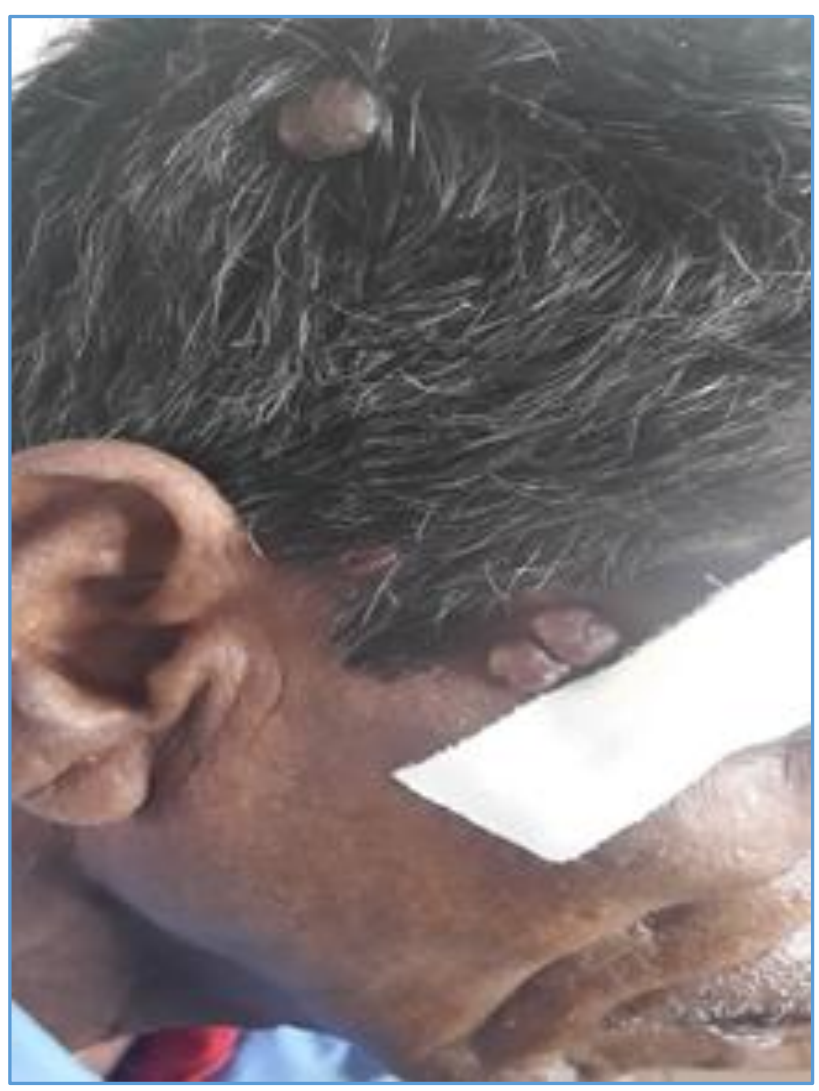

Figure 2. Dermoid Cyst

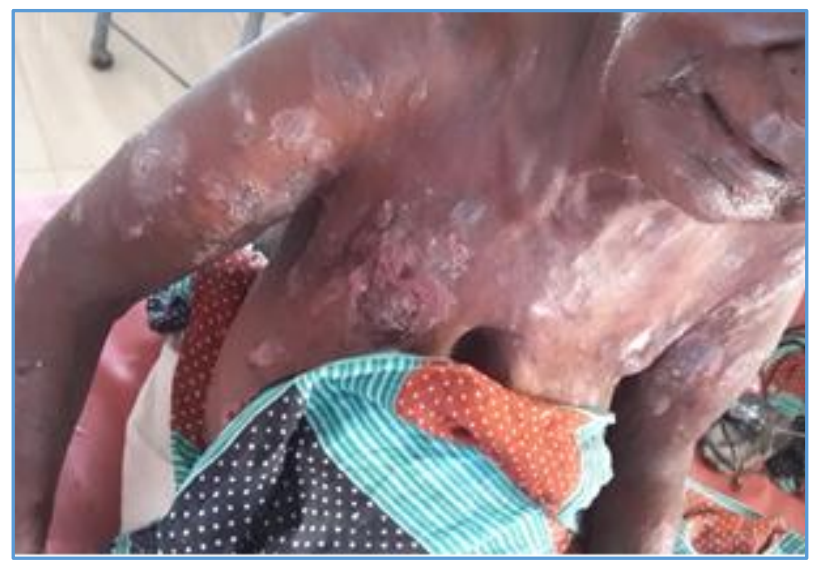

Figure 3. Bullous Pemphigoid

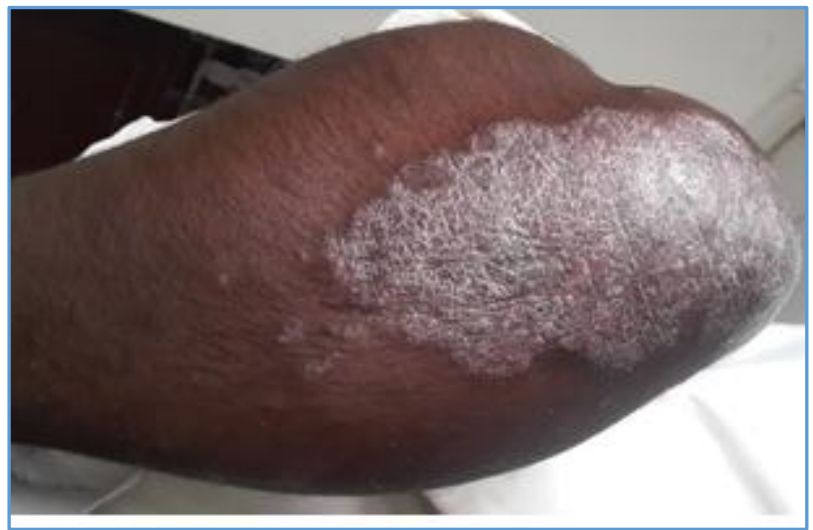

Figure 4. Chronic Plaque Psoriasis

\section{DISCUSSION}

In this study, a total of 300 patients above the age of 60 years were examined. The oldest patient was 85 years. Of these, 197 (66\%) patients were male and 103 (34\%) were female. In the present study, the number of males outnumbered the females which coincide with most of the other studies.5,6,7 Pruritus was the commonest symptom seen in this study and was given by 132 (44\%) patients. In various other studies, pruritus had been the commonest complaint noted varying from $11.5 \%$ to $49.6 \% .5,7-10$ Patange and Fernandez ${ }^{6}$ in their study noted pruritus in $78.5 \%$ of patients, of which $3.8 \%$ had senile pruritus and the rest were associated with cutaneous dermatoses (91.1\%). About 162 (54\%) patients in the present study had comorbid conditions like diabetes mellitus, hypertension, chronic renal failure, ischaemic heart disease, chronic obstructive lung disease, etc with multiple drug usage which may have contributed to development of pruritus. Various physiological changes noted in this study were xerosis, wrinkling, atrophy (thinness of skin), idiopathic guttate hypomelanosis. Xerosis was the commonest physiological change seen in the present study in $93 \%$ of patients. Percentage of xerosis noted in various studies were $7 \%, 6 \quad 12.5 \%, 11 \quad 77 \%, 12 \quad 85 \%{ }^{8}$ and $99.8 \% .^{10}$ Our study correlated with study done by Durai PC et al in which $99.8 \%$ of patients showed xerosis. 10 The high incidence of xerosis could be attributed to less use of emollients and usage of harsher soaps by the subjects of the study who mostly hail from semi-rural areas. Wrinkling was seen in $88 \%$ (264) patients in this study. Tindall and Smith,12 Grover and Narasimhalu, ${ }^{13}$ Beauregard and Gilchrest, ${ }^{8}$ and Durai, Thappa et $\mathrm{al}^{10}$ have reported wrinkling in $94 \%, 95.5 \%, 95.6 \%$ and $99 \%$ patients respectively. Most of the wrinkling seen in this study was on sun exposed areas like the face, neck, forearms and dorsa of hands in the form of glyphic wrinkles. Slight lower incidence of wrinkling in this study may be because of increased tolerance of racially pigmented skin to sunlight. Atrophic wrinkled skin was seen in 63\% (189) of patients in this study. The aged skin becomes fragile, translucent, lax and wrinkled $^{14}$. Tindall and Smith ${ }^{12}$ found an incidence of atrophic wrinkled skin in $94 \%$ patients. Most of the patients in our study were in the age group of 65 to 70 years which may explain the decreased incidence of atrophy as compared to the other study as atrophy is just beginning to manifest at this age. More so, pigmented skin is less susceptible to skin damage.

Idiopathic guttate hypomelanosis was present in 99 (33\%) cases in this study. Three Indian studies mention an 
incidence of about $25 \% 6,8,10$ and one other study by Grover and Narasimhalu ${ }^{13}$ mentioned an incidence of $76.5 \%$. IGH is statistically more often seen in darkened skin than in fair skinned subjects. ${ }^{8}$ This may explain a slightly higher incidence $(33 \%)$ of IGH in the present study compared to other studies. Also, most patients present themselves to be reassured that IGH is not vitiligo, due to the cultural bias against vitiligo.

The range of changes due to chronic sun damage is called dermatoheliosis. The skin change includes senile comedones, irregular pigmentation, wrinkling, scaling, actinic keratoses, elastoses and malignancy. ${ }^{15}$ Senile comedones were found in $84(28 \%)$ cases in this study. Senile comedones was seen in $95.6 \%{ }^{[8]} 81 \%{ }^{[12]}$ and $11.5 \%{ }^{6}$ in various other studies.

The various skin dermatoses seen in the elderly were papulosquamous disorders, eczematous conditions, infections and infestations, pigmentary disorders, benign tumours, miscellaneous skin conditions such as bullous disorders, disorders of keratinisation.

In this study, psoriasis was seen in 27 (9\%) patients. The percentage of psoriasis ranges from $1 \%$ to $11.2 \%$ in various other studies.8,6,11,12,16-18 The percentage of psoriasis in the present study is in concordance with that of the study by Patange and Fernandez ${ }^{6}$ and Sahoo, Singh et al. ${ }^{11}$ Lichen planus was noted in $5 \%$ of patients in this study which is concordant with study by Sahoo, Singh et al.11 In the present study, eczematous conditions were seen in 131 (44\%) patients. The total percentage of eczemas in various studies ranges from $11.9 \%{ }^{19}$ to $58 \% .^{7}$ The percentage of Lichen simplex chronicus (LSC) and contact dermatitis correlates well with the study by Patange and Fernandez. ${ }^{6}$ The percentage of stasis dermatitis in the study is in concordance with the study by Beauregard and Gilchrest. 8 Percentage of seborrhoeic dermatitis in this study correlates well with few other studies.7,18 The increased incidence of LSC and stasis dermatitis in our study may be because of the associated xerosis and pruritus which is high in the patients of this study. Infections and infestations of skin were seen in 96 (32\%) patients. Fungal infections were seen in 11\% (33), viral infection in $8 \%(24)$, leprosy in 6\% (18), pyoderma in $4 \%$ (12) and scabies in 3\% (9) of patients. The percentage of infections and infestations in our study compares well with few studies. Fungal infections are the commonest infections seen in the elderly as noted in our study and in few other studies. ${ }^{19,6}$ Leprosy was seen in $6 \%$ of patients in the study. The percentage of leprosy was $1.5 \%$ in the study by Grover and Narasimhalu. ${ }^{13}$

Pigmentary disorders were seen in 42 (14\%) cases, of these, vitiligo was seen in 27 (9\%) cases, melasma in 15 (5\%). Various studies reported percentage of vitiligo between $1.2 \%$ to $19 \% \cdot 6,11,18$ Our study, as well as that of Patange and Fernandez shows that the incidence of vitiligo is higher in Indian patients. Also, since vitiligo is culturally a dreaded disease in Indian subcontinent, self-referral is higher in all hypopigmentary disorders.

The percentage of seborrhoeic keratosis ranged from $37.5 \%$ to $88 \% \%^{6,8,12}$ in various studies. The findings in this study of seborrhoeic keratosis (47\%) are comparable to that of the study by Beauregard and Gilchrest. 8 The percentage of melanocytic naevi is less in this study compared to the other studies which have a percentage of $46.3 \%^{8}$ and $32.5 \% .^{6}$ No malignant skin conditions were noted in this study. This could be because of the lower incidence of skin cancers in racially pigmented skin.

Among the bullous disorders, only bullous pemphigoid was noted in $3(1 \%)$ patients. In various studies, percentage of bullous disorders ranges from $0.5 \%$ to $4.4 \% \cdot 5,7,10,13,17$ The findings in the present study matches with that of the other studies.

Trophic ulcer was seen in 15 (5\%) cases and keloids in 6 $(2 \%)$ cases in the study. Only one study by Liao $\mathrm{YH}$, Chen $\mathrm{KH}^{7}$ et al mention percentage of keloid as $1 \%$. Other studies do not mention the percentage of keloids. Weismann, Krakauer ${ }^{18}$ et al mention pressure sores in $2.2 \%$ of cases.

Longitudinal ridging of nails was the commonest nail changes seen in 120 (40\%) cases followed by loss of lustre in 112 (37\%) cases, Onychomycosis was seen in 18 (6\%) cases, paronychia was seen in $10(3 \%)$ cases and nail psoriasis was seen in $6(2 \%)$ cases.

\section{CONCLUSION}

Of the 300 patients in this study, the oldest patient was 85 years. Pruritus was the commonest single complaint noted in our study. Xerosis was the commonest physiological change seen in our study. Systemic hypertension was the commonest associated systemic illness noted in our study. Among the various types of eczema, lichen simplex chronicus was the commonest eczema seen in this study. Of the various infections, fungal infection was the commonest. No malignant or premalignant tumours were seen in this study. Bullous pemphigoid was the only bullous disorder encountered in this study. Greying of hair was the commonest hair change seen in this study. Vertical ridging of nails was the commonest nail change seen in this study. This study helps in providing greater understanding of pattern of geriatric dermatoses in a tertiary care centre.

\section{REFERENCES}

[1] Millington GWM, Graham-Brown RAC. Skin and skin diseases throughout life. In: Burns T, Breathnach S, Cox N, et al. eds. Rook's textbook of dermatology. $8^{\text {th }}$ edn. Oxford: Wiley Blackwell Publication 2010;8:21-9.

[2] World Health Organization. Definition of elderly person. 2013. www.who.int/ healthinfo/survey/ageingdefinitionolder/en/index.html.

[3] Fenske NA, Lober CE. Aging and its effects on skin. In: Moschella SL, Hurley HJ. eds. Dermatology. $3^{\text {rd }}$ edn. Philadelphia: WB Saunders 1992:107-22.

[4] Rajan SI, Sarma PS, Mishra US. Demography of Indian aging, 2001-2051. J Aging Soc Policy 2003;15(2-3):1130 .

[5] Yalcin B, Tamer E, Toy GG, et al. The prevalence of skin diseases in the elderly: analysis of 4099 geriatric patients. Int J of Dermatol 2006;45(6):672-6.

[6] Patange VS, Fernandez RJ. A study of geriatric dermatoses. Indian J Dermatol Venerol Leprol 1995;61(4):206-8.

[7] Liao YH, Chen KH, Tseng MP, et al. Pattern of skin diseases in a geriatric patient group in Taiwan: a 7year survey from the outpatient clinic of a university medical center. Dermatology 2001;203(4):308-13.

[8] Beauregard S, Gilchrest BA. A survey of skin problems and skin care regimens in the elderly. Arch Dermatol 1987;123(12):1638-43. 


\section{Jemds.com}

[9] Thaipisuttikul Y. Pruritic skin diseases in the elderly. J Dermatol 1998;25(3):153-7.

[10] Durai PC, Thappa DM, Kumari R, et al. Aging in elderly: chronological versus photoaging. Indian J Dermatol 2012;57(5):343-52.

[11] Sahoo A, Singh PC, Pattnaik S, et al. Geriatric dermatoses in southern Orissa. Indian J Dermatol 2000;45(2):66-8.

[12] Tindall JP, Smith JG. Skin lesions of the aged and their association with internal changes. JAMA 1963;186:1039-42.

[13] Grover S, Narasimhalu C. A clinical study of skin changes in geriatric population. Indian J Dermatol Venereol Leprol 2009;75(3):305-6.

[14] Burrows NP, Lovell CR. Disorders of connective tissue. In: Burns T, Breathnach S, Cox N, et al. eds. Rook's textbook of dermatology. 7 th edn. Vol 4. Blackwell Science 2004:46-7.

\section{Original Research Article}

[15] Sams WM. Sun induced ageing. Clinical and laboratory observations in man. Dermatol Clin 1986;4(3):509-16.

[16] Fadden MC, Hande KO. A survey of elderly new patients at a dermatology outpatient clinic. Acta Dermatol Venerol (Stockh) 1989;69(3):260-2.

[17] Verbov J. Skin problems in the older patients. Practioner 1975;215(1289):612-22.

[18] Weismann K, Krakauer R, Wanscher B. Prevalence of skin diseases in old age. Acta Dermato Venerol 1980;60(4):352-3.

[19] Souissi A, Zeglaoui F, El Feikh N, et al. Skin diseases in elderly: a multicentre Tunisian study. Ann Dermatol Venerol 2006;133(3):231-4. 